\title{
ANALYSING THE HOUSING MARKET STRUCTURE IN ROMANIA AND TURKEY UNDER THE GLOBAL FINANCIAL CRISIS EFFECT
}

\author{
Murat Klyılar ${ }^{1}$ \\ Ali Hepşen ${ }^{2}$
}

\begin{abstract}
Housing is the most important asset in the portfolio of most households. For all households it is an important determinant of quality of life. It is a relatively illiquid investment, with an uncertain capital value, and it is generally highly leveraged, which makes it a potentially important channel of transmission of monetary policy. On the other hand, housing finance is a crucial importance to the macro-economic system as mortgage loans account for a large proportion of bank lending. Indicators related to mortgage market activities and banks' exposures to real estate lending are also useful indicators for monitoring the health of the banking sector. This article aims to present a comparative analysis of the housing market structure in Romania and Turkey before and after the global financial crisis.
\end{abstract}

Keywords: Housing Market, Mortgage Loans, Bank Lending, Financial Crisis, Romania, Turkey

JEL codes: E30, E44, L74, R10, R20, R30

\section{Introduction}

The framework for analyzing the housing structure consists of four elements. These are the political, economic, social and environmental factors that impact directly on housing. Physical and political context consist of natural environment, existing housing stock, government structures and housing policies; whereas economic and social contexts consist of national economy, levels of income, bank lending, mortgage loan rates, demographics and consumption patterns (fig. no 1).

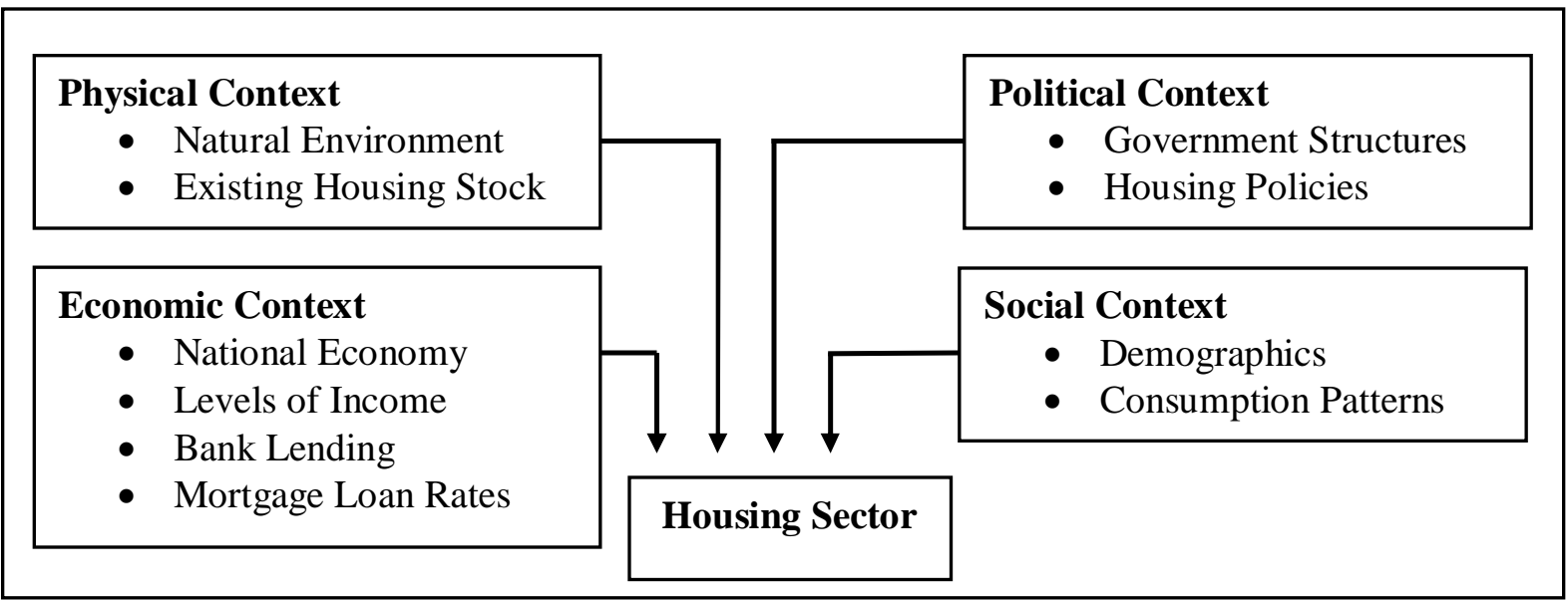

Fig. no. 1 - Framework for the Analysis of the Housing Sector

\footnotetext{
${ }^{1}$ Assoc.Prof.Dr., Department of Finance, Istanbul University, Faculty of Business Administration, Istanbul/ Turkey, email: muratkiy@istanbul.edu.tr

${ }^{2}$ Dr., Department of Finance, Istanbul University, Faculty of Business Administration, Istanbul/ Turkey, email: alihepsen@yahoo.com
} 
Housing is accepted as a fundamental right in the international arena according to the Universal Declaration of Human Rights (1948). Moreover HABITAT II Conferences organized by United Nations have underlined the importance of housing with a main theme of UN Habitat Agenda as "enough housing for everyone" (Habitat II, 1996). Housing matters as a major quality of life issue. Choice in housing is a key component of any democratic society. The way that housing is financed can have a major, positive, impact on the national economy, financial markets and the quality of life. A soundly financed housing sector can play a major role in economic growth and economic stabilization, through the creation of jobs in construction and materials, demand for new enterprises, the financial sector, and indirect impacts through subsidiary activities, including infrastructure, materials, furnishings and services. A well developed housing sector can significantly mitigate unemployment, since housing shortages can severely restrict labor mobility. A developed housing finance system allows capitalization of surplus resources in long term real estate investments, which are relatively safe, inflation proofed and generate a stable flow of revenues. The need for such long-term investment opportunities arises in connection with reform of the social security system and the appearance of pension funds. Long term mortgage loans can be used by banks to improve the term match of assets and liabilities, allowing for effective management of interest rate risk. A well regulated mortgage lending sector increases the stability of the banking system. In order to purchase new houses, households must accumulate capital for down payment. Many researchers have found that the housing sector is responsible for generating a significant portion of household saving. Savings translates into more capital available for investment by the commercial and industrial sectors. Housing matters as a major quality of life issue, particularly in countries where individual control through ownership was previously denied, by law, through limiting options, or by making it unaffordable. While choice in housing is a key component of any democratic society, it can be achieved only on the basis of a sound, marketbased, housing finance system. Real estate represents a major capital resource for many individual households. It constitutes an important form of personal wealth, conditioning popular attitudes towards the state and the economy. Sound housing finance and real estate sectors allow citizens to benefit from this capital, and thus provide the basis for further development of democracy and the free market economy (Black et al, 2000). On the other hand, statistics about housing market activities and banks' exposures to real estate lending are useful indicators for monitoring the health of the banking sector. "Financial Soundness Indicators Compilation Guide" proposed by the International Monetary Fund includes real estate prices, and the ratios of mortgage loans to total loans. These indicators can serve as early warning signals of emerging asset quality problems, as the impact of real estate price shocks generally occurs with a lag and the size of the impact depends on banks' exposure to the real estate market (IMF, 2006).

From the point of these important issues regarding to housing market, this article aims to present a comparative analysis of the housing market structure in Romania and Turkey. The following sections give brief overview of the Romanian and Turkish housing markets. Section IV begins by reviewing some of the existing studies on concerning the housing market developments in both countries. The next section discusses the data issues, presents the empirical model and describes the empirical results. The final section is the conclusion.

\section{Housing Market Developments in Romania}

Romania was the last Central Eastern Europe (CEE) to leave the post-war era behind and begin to implement reform programs in the 1990s. During the transition to capitalism in Romania, private property rights were re-instated to pre-1940s levels. Before this transition, public housing had been the dominant form in the South Eastern Europe region, especially in the major urban areas. In fact, unlike most other CEE, Romania was not highly urbanized, meaning that the percentage of private ownership was higher than in other countries (Palacin and Shelburne 2005). With the transition to a market economy, it was natural that the housing stock would be transferred 
to private ownership. Privatization was accompanied by a series of reforms aimed at creating institutions for housing markets and often by encouraging homeownership. Until 2003, the state deducted more or less the house price based on mostly the region and the usable floor space. After 2003, the state was not longer involved in the house price mechanism (Vries, 2009). Nowadays, the dwelling stock maintained its upward trend and reaching 8.4 million dwellings at the end of 2009 (fig. no 2).

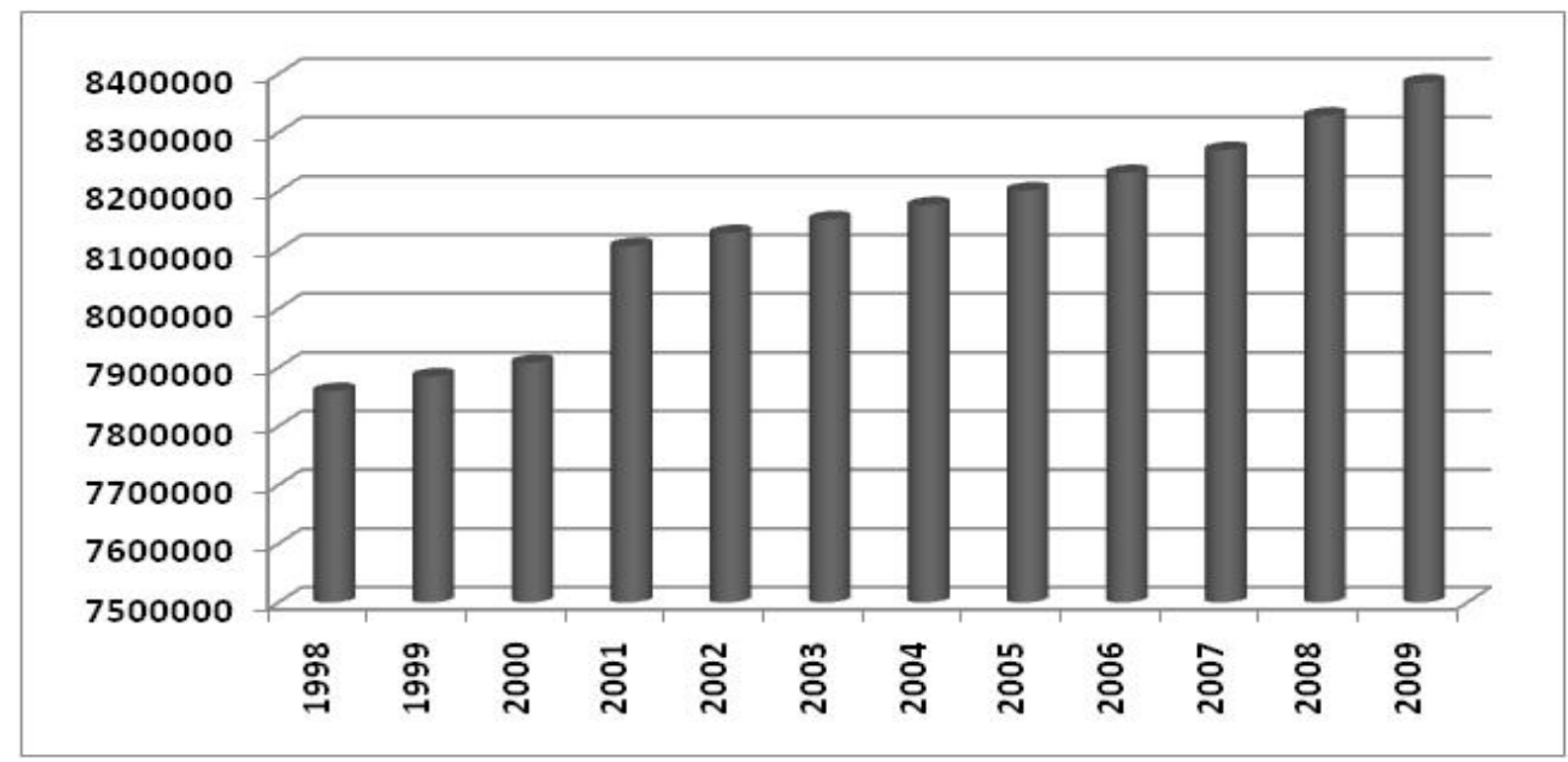

Fig. no. 2 - Dwelling Stock in Romania

By ownership type, within the dwelling stock existing at the end of 2009, the highest weight is held by dwellings under private majority ownership (97.7\%). On the other hand, in 2009, 62,520 dwellings were finished, that is 4,735 less than the previous year but 22,882 more than the year 2006 (NIS, 2010) (table no 1). According to the register of Public Notaries of Romania, the number of transactions in properties in 2009 was about 352,518; that is a $27.28 \%$ decline in comparison with 2008 as a result of the global turmoil.

Table no. 1

Evolution of the Dwelling Stock

\begin{tabular}{|c|c|c|c|c|}
\hline & 2006 & 2007 & 2008 & 2009 \\
\hline $\begin{array}{l}\text { Dwelling Stock (Thousand) } \\
\text { Private Majority Ownership } \\
\text { (Thousand) }\end{array}$ & $\begin{array}{c}8,231 \\
8,036 \\
(97.63 \%)\end{array}$ & $\begin{array}{c}8,270 \\
8,079 \\
(97.69 \%)\end{array}$ & $\begin{array}{c}8,329 \\
8,138 \\
(97.71 \%)\end{array}$ & $\begin{array}{c}8,385 \\
8,192 \\
(97.70 \%)\end{array}$ \\
\hline $\begin{array}{l}\text { Rooms (Thousand) } \\
\text { Private Majority Ownership } \\
\text { (Thousand) }\end{array}$ & $\begin{array}{c}21,273 \\
20,918 \\
(98.33 \%) \\
\end{array}$ & $\begin{array}{c}21,428 \\
21,082 \\
(98.39 \%) \\
\end{array}$ & $\begin{array}{c}21,638 \\
21,294 \\
(98.41 \%) \\
\end{array}$ & $\begin{array}{c}21,841 \\
21,494 \\
(98.41 \%) \\
\end{array}$ \\
\hline $\begin{array}{l}\text { Living Floor (Thousand M2) } \\
\text { Private Majority Ownership } \\
\text { (Thousand M2) }\end{array}$ & $\begin{array}{c}314,542 \\
308,852 \\
(98.19 \%) \\
\end{array}$ & $\begin{array}{c}317,834 \\
312,309 \\
(98.26 \%) \\
\end{array}$ & $\begin{array}{c}322,205 \\
316,685 \\
(98.29 \%) \\
\end{array}$ & $\begin{array}{c}326,413 \\
320,786 \\
(98.28 \%) \\
\end{array}$ \\
\hline $\begin{array}{l}\text { Finished Dwellings } \\
\text { From Private Funds }\end{array}$ & $\begin{array}{c}39,638 \\
34,782 \\
(87.75 \%)\end{array}$ & $\begin{array}{c}47,299 \\
43,000 \\
(90.91 \%) \\
\end{array}$ & $\begin{array}{c}67,255 \\
61,171 \\
(90.95 \%)\end{array}$ & $\begin{array}{c}62,520 \\
56,764 \\
(90.79 \%)\end{array}$ \\
\hline
\end{tabular}


Housing finance market is a crucial importance to the macro-economic system as mortgage loans account for a large proportion of bank lending. Indicators related to mortgage market activities and banks' exposures to real estate lending are also useful indicators for monitoring the health of the banking sector. The mortgage market firstly started in Romania in 2003 and at the end of 2008, before the global financial crisis, residential mortgage loans outstanding amounted to $€ 5.6$ billion, posting a growth of 32\% since 2007 (NBR, 2010). However the lending has increased moderately in Romania (3.20\%) in 2009, most of the CEE countries including Estonia, Latvia, Lithuania and Hungary the amount of outstanding loans has declined (Kahre, 2010). The below figure shows total outstanding residential loans from 2004 to 2009.

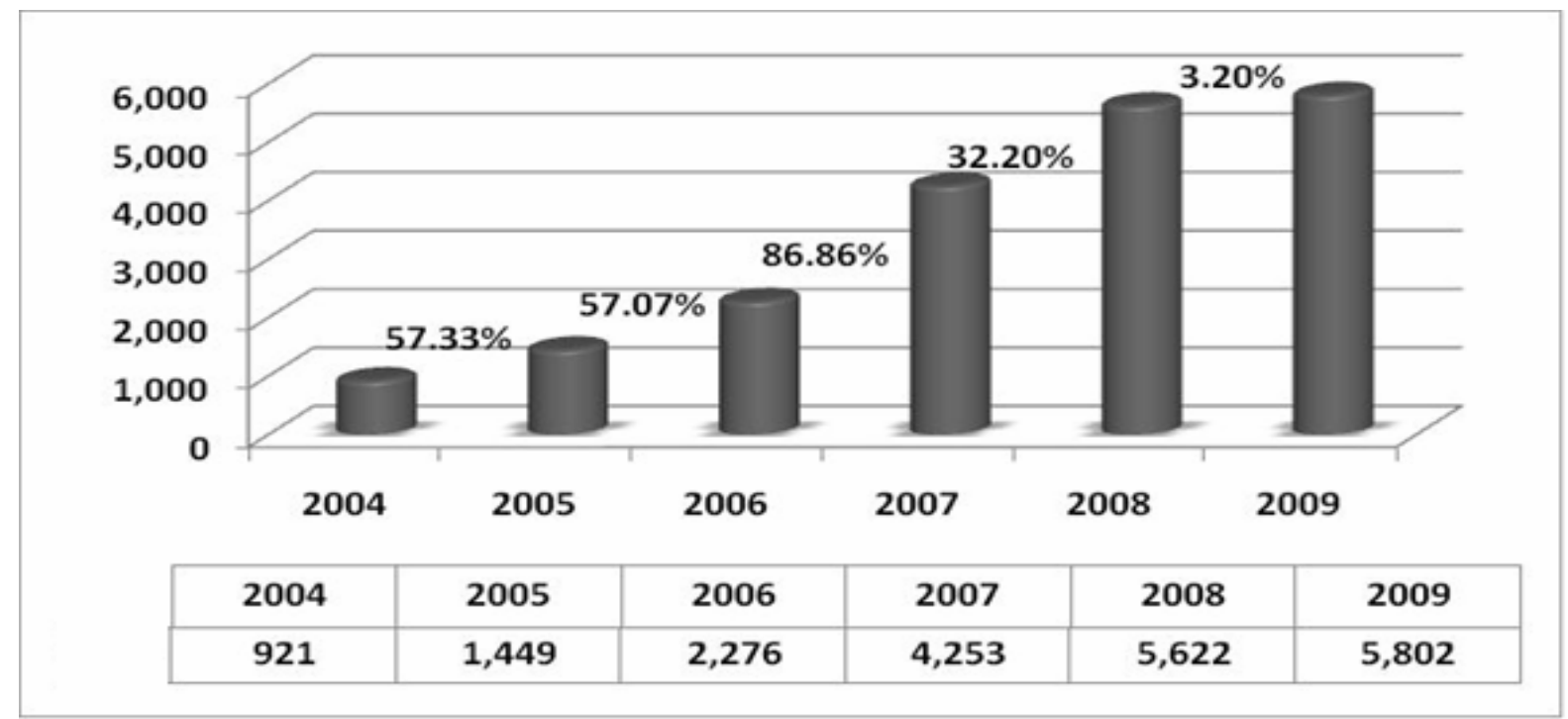

Fig. no. 2 - Total Outstanding Residential Loans (€ Million)

One of the fundamental factors in housing market is the mortgage loan rates. However the Romanian housing market is mostly foreign currency dominated, EURO based rates are so important. As seen from the below figures, there is an observable downward trend in the evolution of interest rates, and in July 2010 the average interest rates for EURO and RON denominated long term credits (above 5 years) granted to individuals was $6.15 \%$ and $10.69 \%$ respectively (NBR, 2010).

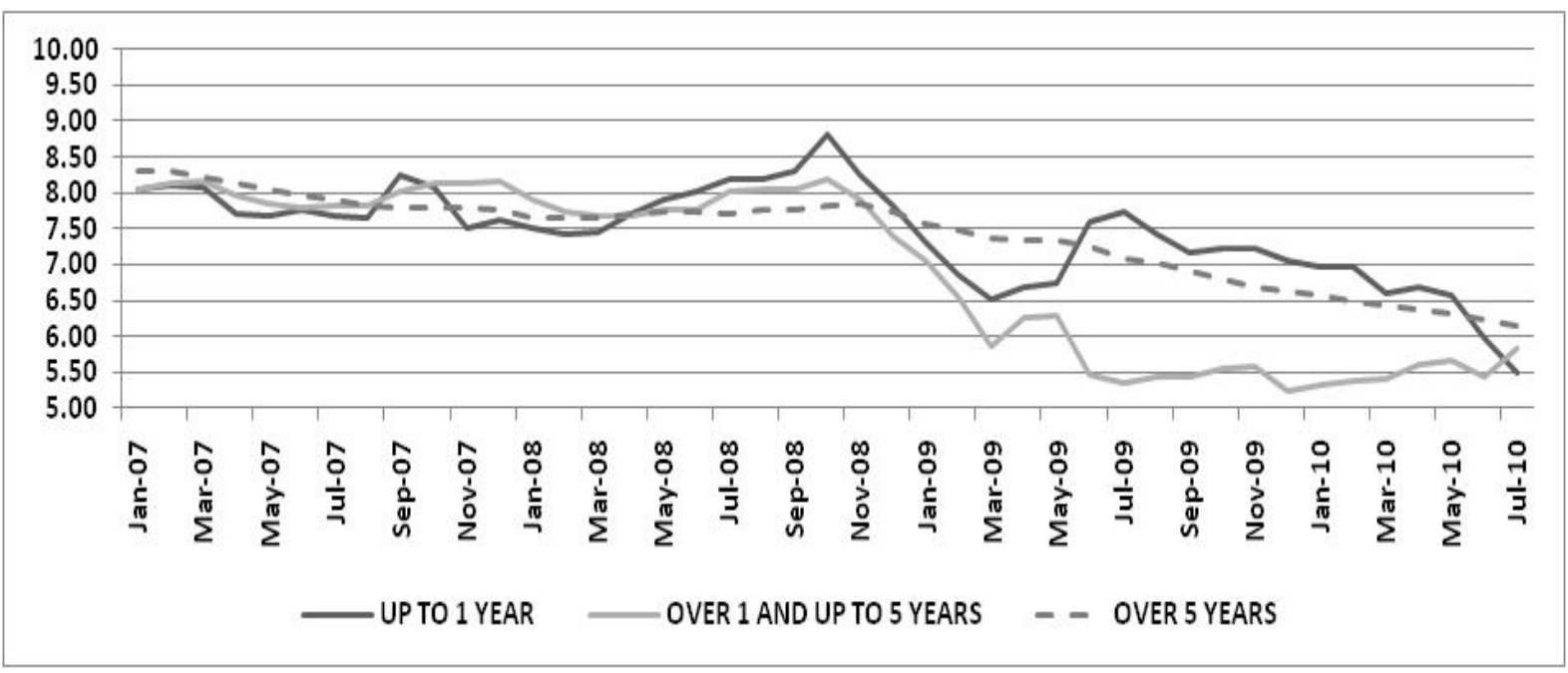


Fig. no. 3 - Mortgage Loans Interest Rate (EURO Dominated)

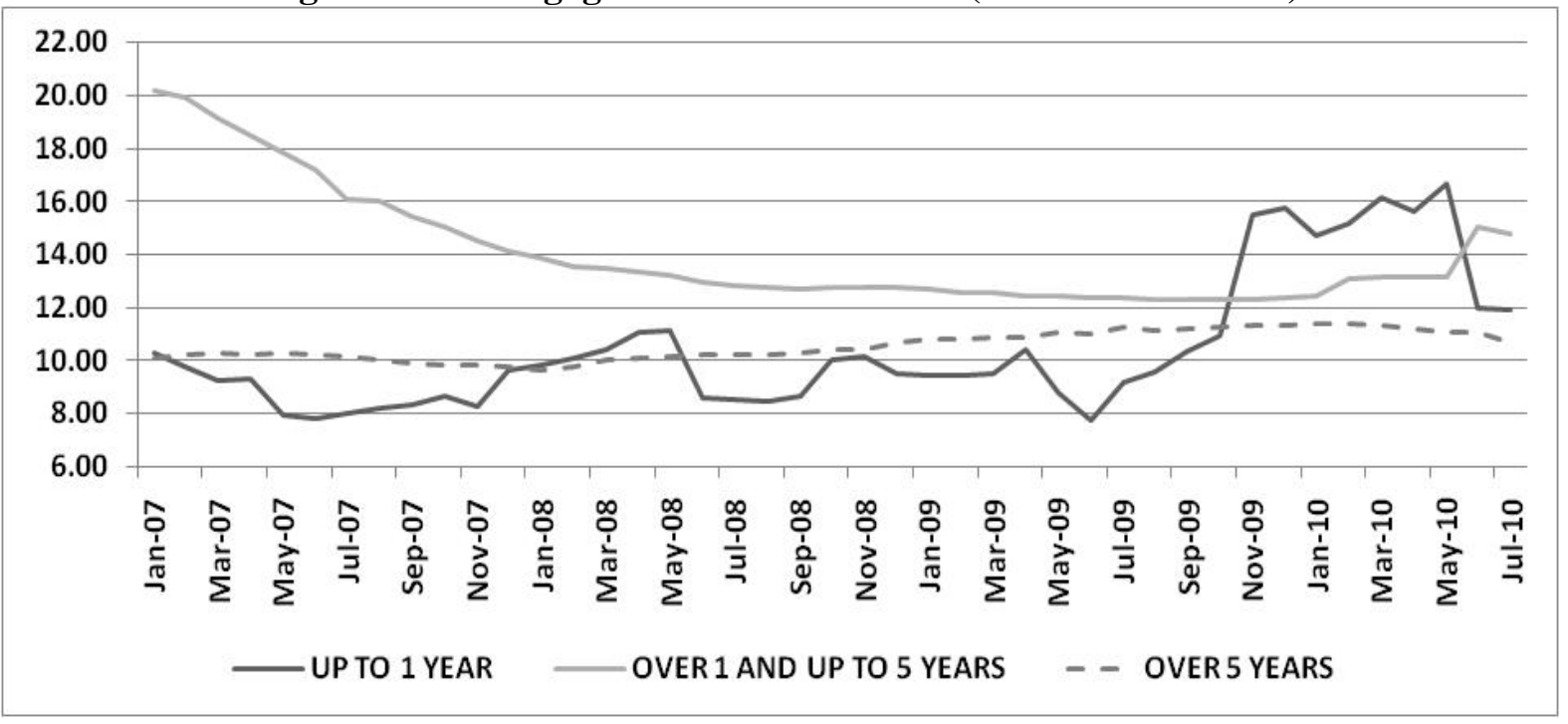

Fig. no. 4 - Mortgage Loans Interest Rate (RON Dominated)

However, house price indices are used as a macro-economic indicator of inflation, as a measurement of wealth, as a deflator for national accounts, as an input into an individual citizen's decision making on whether to invest a residential property; Romania does not have an official index. On the other hand, according to Bălăcescu and Tănăsoiu (2009), the population informing with the help of various specific sites that offer information on real estate prices in the cities of Romania, but all this information refer to price list, and not actual transaction prices, but most of they have only a speculative role.

\section{Housing Market Developments in Turkey}

Real estate is one of the important and traditional investments for Turkish household due to several reasons. Industrialization and renewal are the main components of the strong domestic demand for real estate. After 2000-2001 financial crises, Turkish economy has showed extraordinary economic growth until negative impacts of global financial crisis in the 2008 . European Union (EU) full membership candidacy, political and economic stability, and increasing in direct and portfolio investments are the main components of the growth period (Coşkun, 2010). In addition to these factors, during the past half century, the population of Turkey has almost tripled and reached 72.6 million in 2009. On the other hand, there has been a dramatic increase in the total number of households in Turkey since 1960 from about 5 million to 15 million with the average size of the household declining from 5.7 persons to 4.5 persons (TurkStat, 2010). Another important phenomenon that leads to increase in housing demand in Turkey is the rapid pace of urbanization and the declining share of rural population in the country. The urbanization process has been accompanied by immigration from rural to urban areas at unprecedented rates. According to Turkish Statistical Institute, the share of urban population increased from 30 percent in 1960 to over 70 percent by 2009.

On the other hand, the structure of the Turkish housing finance market has been changed since the 2000-2001 banking crisis. There has been a considerable increase in total outstanding residential loans for the period 2001-2009. As to data of the Central Bank of Turkey while total mortgage loans issued by Turkish banks have been only 33 million Euros during the end of 2001, same figure has been 19.7 billion Euros during the end of 2009. 
Table no. 2

Development of Turkish Housing Finance Market

\begin{tabular}{|l|c|c|}
\hline Year & Total Outstanding Residential Loans & Percentage Change \\
\hline $\mathbf{2 0 0 1}$ & 33 Million Euro & \\
\hline $\mathbf{2 0 0 2}$ & 180 Million Euro & $437.5 \%$ \\
\hline $\mathbf{2 0 0 3}$ & 464 Million Euro & $158.5 \%$ \\
\hline $\mathbf{2 0 0 4}$ & 1.5 Billion Euro & $215.4 \%$ \\
\hline $\mathbf{2 0 0 5}$ & 7.4 Billion Euro & $404.9 \%$ \\
\hline $\mathbf{2 0 0 6}$ & 12.9 Billion Euro & $75.0 \%$ \\
\hline $\mathbf{2 0 0 7}$ & 17.3 Billion Euro & $33.7 \%$ \\
\hline $\mathbf{2 0 0 8}$ & 19.6 Billion Euro & $13.5 \%$ \\
\hline $\mathbf{2 0 0 9}$ & 19.7 Billion Euro & $0.4 \%$ \\
\hline
\end{tabular}

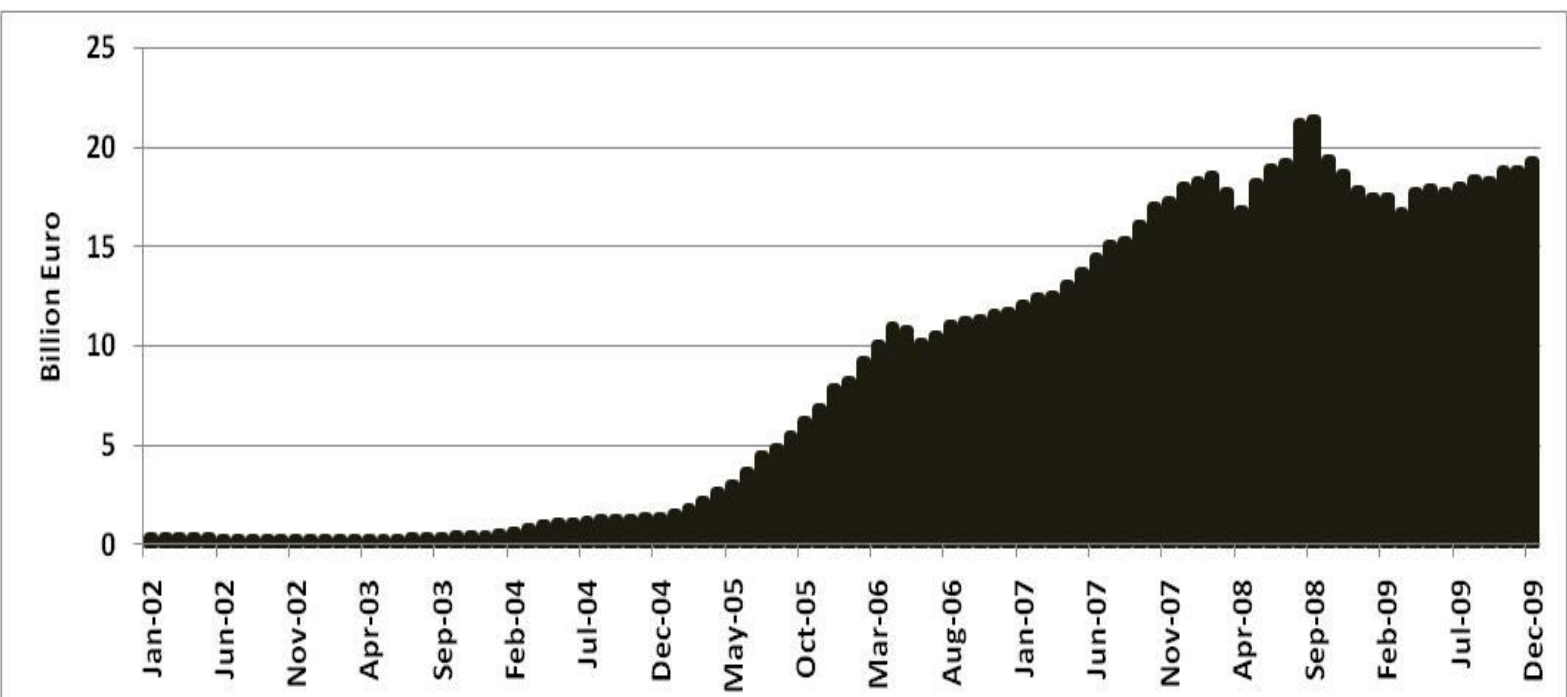

Fig. no. 5 - Total Outstanding Residential Loans

The main reason for Turkish citizens starting to obtain housings by finance sector is the financial stability in accordance with economic recovery and dropping mortgage loan interest rates depending on this stability (see below fig.).

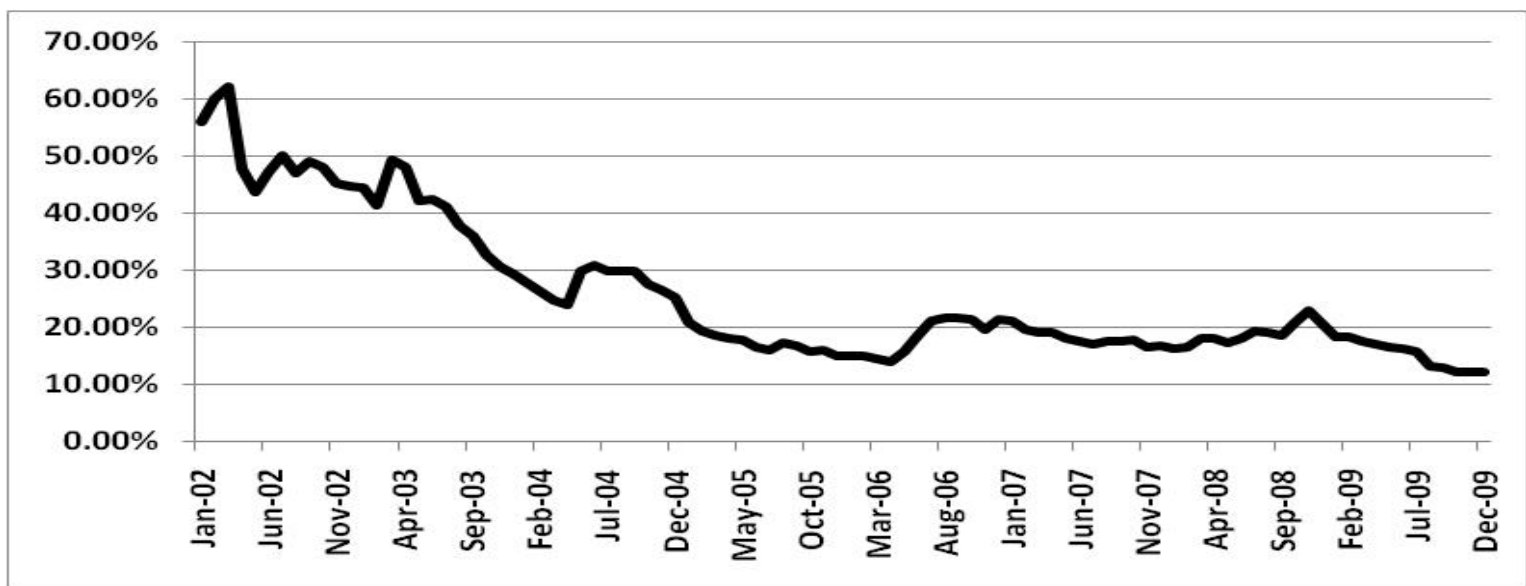

Fig. no. 6 - Mortgage Loans Interest Rate (TL Dominated, for 10 Years Maturity Loan) 
Compared to the previous years (i.e. average mortgage loan rate was $50.03 \%$ in the year 2001 for 10 -years maturity loans and $15.16 \%$ in the year 2009), mortgage loan rates have dropped. As a result of this, these loans became redeemable and this has increased the mortgage loan demand. Likewise, depending on the economic recovery experienced in Turkey, borrowing need of public sector has decreased. Therefore, banks started to transfer their resources to loans other than government securities. On this account, residential loan demand got increased.

\section{Review of Literature}

As housing markets are becoming increasingly important for the national economies, various researchers in both countries have directed their attention to them in the recent past. For instance, Turcu et al (2009) take into consideration factors such as the residential market of both new and old products, comparing their evolution up until March 2009 and studying their prices, units sold, and latest projects in Romania. But Kahre (2010) has focused on the development of lending boom and has brought out the concerns about the overheating housing market. She concentrate on analyzing the CEE countries (including Romania) housing and lending market development in 2002-2009 and try to analyze which of these countries have the greatest potential for housing market recovery? The results of her study suggest that countries with higher housing debt had stronger real estate booms and the current bust-cycle has caused much steeper decline in prices. In addition Egert and Mihaljek (2007) study the determinants of house prices in eight transition economies of CEE (including Romania) and 19 OECD countries. In the study, the main question addressed is whether the conventional fundamental determinants of house prices, such as gross domestic product (GDP) per capita, real interest rates, housing credit and demographic factors, have driven observed house prices in CEE. By using the panel DOLS technique, they established a strong positive relationship between per capita GDP and house prices. They also establish robust relationships between real interest rates and house prices, as well as between housing (or private sector) credit and house prices, in both CEE and OECD countries. House prices in CEE have tended to increase twice as fast for an equivalent drop in real interest rates than house prices in OECD countries. On the other hand, house prices in OECD countries seem to respond roughly two times more strongly to credit growth compared with CEE economies. The observed rapid credit growth in CEE may therefore have smaller impact on the growth of house prices than is usually extrapolated from relationships obtained for the OECD countries. Demographic factors and labor market developments also play an important role in house price dynamics. They seem to affect house prices more strongly in central and eastern Europe than in OECD countries. But Vries (2009) analyses another aspect of the Romanian housing market. The author uses a hedonic regression model to examine the construction of real estate databases and the valuation of properties in Buzău, Romania. All of these studies provide a great deal of information about Romanian housing market.

However, in contrast to the above mentioned studies, there are numerous studies about the housing market in Turkey; for instance, Yetgin and Lepkova (2007) have been carried out detailed SWOT analysis for Turkish real estate market in their research paper. The authors regard "economic, geographic and demographic scales of Turkey, young and dynamic manpower, international experience and knowledge" as strengths; "negative aspects of the national economy and limited investments, negative aspects of the utilization of resources, insufficient capital accumulation and financial substructure, problems with enforcement of the laws and regulations, negative aspects of the bureaucratic structure of the state, insufficient education level, insufficient national research and development substructure, insufficient cooperation between universities and industrialists and unhealthy competition in the real estate sector" as weaknesses; "the need to renew the existing stock of infrastructures and buildings, increase of directly inflow of foreign capital, development in the tourism sector and the demand for construction contracts in foreign markets" as opportunities; and finally "earthquake risk, education level of technical manpower and 
possible effects of future economic crisis" as threats. In addition, Coşkun (2010) determines advantages and disadvantages of Turkish real estate market in his study. He classifies "positive fundamentals (geo-political position; EU candidacy; industrialization; growing/stable economy etc.), positive sides of demographics and urbanization, public policies on real estate supply, dynamic and creative entrepreneurship, motives in domestic demand and other factors for strong demand, developments in regulatory framework and developing academic knowledge" as advantages; "fundamental instabilities (implicit socio-economic instability, unemployment, inequality of income, poverty etc.), infrastructure - related problems (inadequacy of water, electricity and other public services, etc.), institutional deficiencies (complicated/problematic/less effective legal system applicable to real estate), irregular activities (less transparency on real estate markets, capturing legal system), inefficient finance-real estate link, problems in real estate appraisal for both market/public based transactions and problems from the land/cadastral information systems, and decision-making process of public sector/judicial system" as disadvantages for Turkish real estate markets.

\section{Data, Theoretical Framework and the Empirical Results}

The international macroeconomic and financial environment has undergone major negative changes since the global financial crisis. International financial turbulences which started in 2007 translated into a full-fledged crisis one year later. Starting September 2008, this crisis has intensified, affecting seriously world economic growth. As discussed above, however the total outstanding residential loans have increased $3.20 \%$ in Romania and $0.04 \%$ in Turkey during the year 2009; our aim is to identify how the changes in world economic growth (GDP) affect the housing market activities both in Romania and Turkey.

In our study, we use the change in real world GDP growth (WGDP), which has been released by the International Monetary Fund, as the substitution variable for a world economic growth. We therefore use real percentage changes in residential loans over GDP (RLGDP), number or residential building permits (RBP), number of dwelling stock (NDS), long term mortgage loan (over 5-years maturity) interest rates (MIR) for both countries. All variables, which are gathered from the National Institution of Statistics (NIS) and Central Banks, are transformed into real terms by deflation with the consumer price index (CPI) and since the data for all variables, for the examination period between 2004 and 2009, is not available monthly, the annual and quarterly series on these data are converted into monthly data by constant conversion technique so as to make use of them together.

This study uses Granger-causality test proposed by Granger (1969) for testing the causality between the world economic growth and housing market variables for Romania and Turkey. The hypotheses of interest are as follows:

$\mathrm{H}_{01}$ : Changes in world economic growth does not Granger causes changes in housing market activities in Romania

$\mathrm{H}_{02}$ : Changes in world economic growth does not Granger causes changes in housing market activities in Turkey

As mentioned above, the procedure used in the study for testing statistical causality between the stock market and the economy is the "Granger-causality" test developed by C.W.J. Granger in 1969. The Granger causality tests determine the predictive content of one variable beyond that inherent in the explanatory variable itself. The variables to be used in the Granger Causality test are assumed to be stationary. In the case of the study's data set, test statistics for unit root have already been calculated. 
The test for causality can be based on an F-value (Gujurati, 2004). The estimated F-values of causality test are reported in the below table. Column two gives the direction of causality and column three shows the F-values for the null-hypothesis of no causality between the variables.

Results of Granger Causality Test

\begin{tabular}{|l|l|c|c|}
\hline \multicolumn{1}{|c|}{ Variables } & \multicolumn{1}{c|}{ Direction of Causality } & F-Value & Causality \\
\hline$\Delta \ln ($ WGDP $)-\Delta \ln ($ TR-RLGDP $)$ & $\Delta \ln ($ WGDP $\rightarrow \Delta \ln ($ TR-RLGDP $)$ & $13.54^{*}$ & Yes \\
\hline$\Delta \ln ($ WGDP $)-\Delta \ln ($ TR-RBP $)$ & $\Delta \ln ($ WGDP $\rightarrow \Delta \ln ($ TR-RBP $)$ & 0.32 & No \\
\hline$\Delta \ln ($ WGDP $)-\Delta \ln ($ TR-NDS $)$ & $\Delta \ln ($ WGDP $) \rightarrow \Delta \ln ($ TR-NDS $)$ & 1.15 & No \\
\hline$\Delta \ln ($ WGDP $)-\Delta \ln ($ TR-MIR $)$ & $\Delta \ln ($ WGDP $) \rightarrow \Delta \ln ($ TR-MIR $)$ & $7.82^{* *}$ & Yes \\
\hline$\Delta \ln ($ WGDP $)-\Delta \ln ($ ROM-RLGDP $)$ & $\Delta \ln ($ WGDP $\rightarrow \Delta \ln ($ ROM-RLGDP $)$ & $10.47^{* *}$ & Yes \\
\hline$\Delta \ln ($ WGDP $)-\Delta \ln ($ ROM-RBP $)$ & $\Delta \ln ($ WGDP $) \rightarrow \Delta \ln ($ ROM-RBP $)$ & 0.35 & No \\
\hline$\Delta \ln ($ WGDP $)-\Delta \ln ($ ROM-NDS $)$ & $\Delta \ln ($ WGDP $) \rightarrow \Delta \ln ($ ROM-NDS $)$ & 0.73 & No \\
\hline$\Delta \ln ($ WGDP $)-\Delta \ln ($ ROM-MIR $)$ & $\Delta \ln ($ WGDP $) \rightarrow \Delta \ln ($ ROM-MIR $)$ & $9.78^{* *}$ & Yes \\
\hline
\end{tabular}

$*$ and $* *$ show that null hypothesis is rejected at $1 \%$ and $5 \%$ level of significance respectively.

The results indicate that changes in world economic growth do "Granger cause" changes in residential loans over GDP and long term mortgage loan (over 5-years maturity) interest rates for both countries. Changes in residential loans over GDP and long term mortgage loan interest rates are directly influenced by the changes in world economic growth and that is the case for both countries.

\section{Conclusion}

This paper has analyzed the interaction between changes in world economic growth before and after the global financial crisis, and housing market variables in the case of Romanian and Turkish economies. At the beginning of the last decade, the world economy faced a relative growth, prolonged by the increasing of capital flows. Due to positive signs in the global economy Romanian and Turkish residential markets attracted local, as well as foreign investors. On the other hand, the international macroeconomic and financial environment has undergone major negative effects since the global financial crisis. International financial turbulences which started in 2007 translated into a full-fledged crisis one year later. Starting the third quarter of 2008, this crisis has intensified, affecting seriously world economic growth. From the point of this perspective, our aim is to investigate whether changes in world economy affects housing market variables in Romania and Turkey or not. The main findings suggest that changes in world economic growth directly affect volume of residential loans over GDP and interest rates in both countries not surprisingly.

\section{References}

1. Bălăcescu, A., Tănăsoiu, G.L., 2009. Overall Analysis about the Evolution of Real Estate Market in Romania, Economics, Vol.9, No.3, pp.25-33

2. Black et al, 2000. Solving the Housing Problem, United States Agency for International Development, Central Europe Development Office, Working Paper, Warsaw

3. Coşkun, Y., 2010. An Analysis of the Strengths and Weaknesses of the Turkish Real Estate Market, European Real Estate Society Conference Paper, Milano

4. Egert, B., Mihaljek, D., 2007. Determinants of House Prices in Central and Eastern Europe, Bank for International Settlement, Working Paper, No.236, Basel

5. Granger, C.W.J., 1969. Investigating Causal Relations by Econometric Models and Cross Spectral Methods, Econometrica, Vol.37, pp.424-438 
6. Gujurati, D.N., 2004. Basic Econometrics, Fourth Edition, The McGraw-Hill, New York.

7. Kahre, K., 2010. Which Central Eastern European Country Has the Greatest Potential for Housing Market Recovery?, European Real Estate Society Conference Paper, Milano

8. International Monetary Fund, 2006. Financial Soundness Indicators Compilation Guide, Monetary and Financial Systems and Statistics Departments, Washington

9. National Bank of Romania, 2010. Financial Stability Report, Bucharest

10. National Institute of Statistics, 2010. Romania in Figures 2010, Bucharest

11. Palacin, J., Shelburne, R.C., 2005. The Private Housing Market in Eastern Europe and the CIS, United Nations Economic Commission for Europe, Discussion Paper, Geneva

12. Turcu et al, 2009. Analyzing the Romanian Residential Market under the Global Financial Crisis Effect, Romanian Economic and Business Review, Vol.4, No.3, pp.215-228

13. United Nations, 1996. HABITAT II Conference Conclusion Report, Istanbul

14. Vries, P., 2009. Determinants of House Prices in Romania: How to Measure House Prices in a New EU State, European Real Estate Society Conference Paper, Stockholm 